\title{
Evidences that human disturbance simplify the ant fauna associated a Stachytarpheta glabra Cham. (Verbenaceae) compromising the benefits of ant-plant mutualism
}

\author{
Barbosa, BC. .* , Fagundes, R. ${ }^{b}$, Silva, LF. ${ }^{a}$, Tofoli, JFV. , Santos, AM. ', Imai, BYP. , \\ Gomes, GG. ${ }^{e}$, Hermidorff, MM. ${ }^{f}$ and Ribeiro, SP. ${ }^{a}$
}

${ }^{a}$ Laboratório de Ecologia Evolutiva de Insetos de Dossel e Sucessão Natural, Departamento de Biodiversidade, Evolução e Meio Ambiente, Universidade Federal de Ouro Preto - UFOP, Campus Morro do Cruzeiro, s/n., Bauxita, CEP 35400-000, Ouro Preto, MG, Brazil

${ }^{b}$ Laboratório de Ecologia Comportamental e Interações, Programa de Pós-Graduação em Ecologia e Conservação de Recursos Naturais, Departamento de Biociências, Universidade Federal de Uberlândia - UFU, Campus Umuarama, Avenida Pará, 1720, Umuarama, CEP 38400-902, Uberlândia, MG, Brazil

'Laboratório de Biologia Molecular, Departamento de Microbiologia Agrícola, Universidade Federal de Viçosa - UFV, Avenida Peter Henry Rolfs, s/n, Campus Universitário, CEP 36570-900, Viçosa, MG, Brazil

${ }^{d}$ Laboratório de Zoologia dos Vertebrados, Departamento de Biodiversidade, Evolução e Meio Ambiente, Universidade Federal de Ouro Preto - UFOP, Campus Morro do Cruzeiro, s/n, Bauxita, CEP 35400-000, Ouro Preto, MG, Brazil

'Laboratório de Parasitologia e Epidemiologia Molecular, Programa de Pós-Graduação em Bioquímica Agrícola, Departamento de Bioquímica e Biologia Molecular, Universidade Federal de Viçosa - UFV, Avenida Peter Henry Rolfs, s/n, Campus Universitário, CEP 36570-900, Viçosa, MG, Brazil

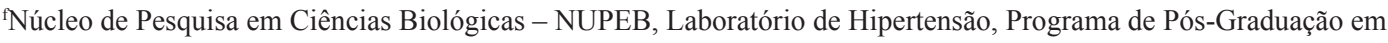
Ciências Biológicas, Departamento de Ciências Biológicas, Universidade Federal de Ouro Preto - UFOP, Campus Morro do Cruzeiro, s/n., Bauxita, CEP 35400-000, Ouro Preto, MG, Brazil

*e-mail: babic.barbosa@gmail.com

Received: May 2, 2013 - Accepted: September 30, 2013 - Distributed: March 31, 2015

(With 3 figures)

\begin{abstract}
Interaction among species, like ants and plants through extrafloral nectaries (EFNs), are important components of ecological communities' evolution. However, the effect of human disturbance on such specific interactions and its ecological consequences is poorly understood. This study evaluated the outcomes of mutualism between ants and the EFN-bearing plant Stachytarpheta glabra under anthropogenic disturbance. We compared the arthropod fauna composition between two groups of twenty plant individuals, one in an area disturbed by human activities and one in a preserved area. We also check the plant investment in herbivory defense and the consequential leaf damage by herbivore. Our results indicate that such disturbances cause simplification of the associated fauna and lack of proper ant mutualist. This led to four times more herbivory on plants of disturbed areas, despite the equal amount of EFN and ant visitors and low abundance of herbivores. The high pressure of herbivory may difficult the re-establishment of $S$. glabra, an important pioneer species in ferruginous fields, therefore it may affect resilience of this fragile ecological community.
\end{abstract}

Keywords: arthropods, environmental conservation, Myrmecophily, rupestrian fields, Stachytarpheta glabra.

\section{Evidências de que os impactos antrópicos simplificam a fauna de formiga associada a Stachytarpheta glabra (Verbenaceae) comprometendo os benefícios do mutualismo formiga-planta}

\section{Resumo}

As interações entre espécies, como por exemplo formigas e plantas através de nectários extraflorais (NEFs), são importantes componentes na evolução das comunidades. Entretanto, pouco é conhecido sobre os efeitos dos impactos antrópicos em interações específicas e suas consequências ecológicas. Este estudo avaliou os resultados do mutualismo entre formigas e NEF em Stachytarpheta glabra em área impactada pela atividade humana. Nós comparamos a composição e estrutura da fauna de artrópodes, em quarenta plantas de dois grupos, um impactado por atividades humanas e o outro preservado. Nós também avaliamos o investimento da planta em defesas contra herbívoros e os danos foliares causados por herbívoros. Nossos resultados indicam que os distúrbios causam a simplificação da fauna 
associada e a ausência de uma formiga mutualista anti-herbívoros. Isto leva a quatro vezes mais herbivoria nas plantas da área impactada, a despeito da mesma quantidade encontrada para NEF e formigas visitantes. A grande pressão de herbivoria pode dificultar o reestabelecimento de $S$. glabra, uma espécie pioneira importante nos campos ferruginosos, dessa forma, afetando a resiliência dessa comunidade ecológica ameaçada.

Palavras-chave: artrópodes, conservação ambiental, Mirmecofilia, campos rupestres, Stachytarpheta glabra.

\section{Introduction}

Some plant species have adaptations to promote and facilitate interaction with ants: food bodies, domatia and extrafloral nectaries (hereafter EFNs; Webber et al., 2007). In this interactions, plants provide food or shelter to ants as a reward for protection against herbivores (Bentley, 1977; Del-Claro et al., 1996; Rosumek et al., 2009). As a result, these plants may have reduced herbivory on leaves, buds and flowers and a high reproductive success (Almeida and Figueiredo, 2003; Heil et al., 2004; RicoGray and Oliveira, 2007; Rosumek et al., 2009). However, the outcomes of these interactions may change over time, seasonality, identity and number of species involved and level of environmental disturbance (Del-Claro and Oliveira, 1999, 2000; Lach et al., 2010; Rico-Gray et al., 2004).

Environmental disturbances affect ecological communities in many ways, specially decreasing diversity of species and eroding interaction networks (Del-Claro and Torezan-Silingardi, 2009; Naeem, 1998; Philpott et al., 2010; Pimm, 1984). This may change the direction and strength of ecological interactions (Piovia-Scott, 2011). As a consequence, changes in the outcomes of these interactions may have further effects on the entire ecosystem (Margulis and Fester, 1991; Six et al., 2011). However, relatively little attention has been paid to its effects on mutualisms compared with other interaction like predation and competition (Begon et al., 1996; Six et al., 2011).

Environmental perturbations may cause loss of photosynthetic tissue and lead to the plant regrowth. At this stage the plant is susceptible to herbivore attack due to low physical and chemical protection of young leaves and their nutritional quality (Spiller and Agrawal, 2003). Therefore myrmecophilous plants tend to invest more in production of ant attractors and enhance their protection (Agrawal and Rutter, 1998; Heil et al., 2001; Mondor and Addicott, 2003; Ness, 2003; Wäckers et al., 2001). In a study on the effect of fire on ant-plant interaction through EFNs, Alves-Silva (2011) demonstrated that Banisteriopsis malifolia produces greater amount of nectar in post-fire regrowth. This leads to increase in the number of ants visiting and protecting the plant against herbivores. This author has once again demonstrated this phenomenon in a different year for the same system Banisteriopsis malifoliaant (Alves-Silva and Del-Claro, 2013). The breaking and pruning of plants, such as caused by windstorms, can lead to increased nectar production in young leaves and consequently the amount of ants (Piovia-Scott, 2011).

Stachytarpheta glabra Cham. (Verbenaceae) is a rupestrian shrub, which has leaves carrying many EFNs, a food source for many arthropods, mainly ants (Antonini et al., 2005;
Vincent et al., 2002). This plant is endemic of Serra do Espinhaço, the largest Brazilian mountain system in the south eastern, rich in endemism and sensitive to human impacts (Drummond et al., 2005; Giulietti et al., 2005; Jacobi and Carmo, 2008). S. glabra grows only in the ironstone outcrops vegetation, known as Cangas (Viana-Silva and Jacobi, 2012; Viana and Lombardi, 2007), a ecosystem exclusively of this region. These habitats are among the most endangered and little studied in the Neotropical region and the potential recovery of degraded areas is unknown (Jacobi et al., 2008; Viana and Lombardi, 2007). In this abiotically constrained environment, the ant fauna and their behavior are poorly known even though being important on multitrophic interactions with plants and herbivores (Byk and Del-Claro, 2011; Fagundes et al., 2013; Romero, 2002; Sousa-Souto et al., 2008).

In this study, we evaluated the effects of human impacts on the interaction between ants and S. glabra and the richness and abundance of guilds of arthropods associated with $S$. glabra. We assume that the human disturbance will favor the ant-plant interaction through increased production of EFNs and attracting ants and reducing the amount of herbivores and herbivory on S. glabra (AlvesSilva and Del-Claro, 2013; Piovia-Scott, 2011). We tested the hypothesis that environmental degradation leads to lower abundance and richness, and different composition of arthropods associated with S. glabra (hypothesis 1). The plant produces higher number of EFNs in disturbed area (2), attracting a larger number of individuals and species of ants (3). This leads to smaller amount of herbivores and plant herbivory in the disturbed area (4). Other feeding guilds of arthropods, such as predator spiders, are only affected by environmental degradation and have lower abundance and richness in plants of disturbed area (5).

\section{Material and Methods}

The study was conducted from June to July of 2010 in a fragment of ferruginous rupestrian field with 20 ha, at $1.250 \mathrm{~m}$ high, located in Ouro Preto, Brazil $\left(20^{\circ} 18^{\prime} 45^{\prime \prime} \mathrm{S}\right.$, $\left.43^{\circ} 33^{\prime} 45^{\prime} \mathrm{W}\right)$. The soil consists of a concretion of iron sesquioxide forming hard substrates that are partially penetrable by plants (Antonini et al., 2005; Rosière and Chemale, 2000). The vegetation is dominated by shrub and tree species, especially Veloziaceae, Asteraceae and Malpighiaceae (Jacobi and Antonini, 2008). We selected two neighboring fragments of vegetation: one preserved and one disturbed. The disturbance consists in annual fires and disposal of exogenous soil, in the midst of which the populations grows. In addition, the area was invaded 
by two exotic plants: Melinis minutiflora P. Beauv. and Dicranopteris nervosa (Kaulf.) Maxon.

In each fragment, we selected 20 plants with similar architecture (height, branches, and crown diameter) and minimum distance of $5 \mathrm{~m}$ from each other (Nahas and DelClaro, 2011), which we consider as independent samples. We collected the arthropods with an entomological umbrella (Ribeiro et al., 2005). Each plant was hit 10 times with a $1 \mathrm{~m}$ of length stick and the specimens that fell on the umbrella were collected. Insect species were identified at the Laboratory of Evolutionary Ecology of Canopy Insects and Natural Succession, at the Federal University of Ouro Preto (UFOP), and spiders in the Laboratory of Arachnology, at the Federal University of Minas Gerais (UFMG). Species vouchers were deposited in both collections. The species were separated into feeding guilds according to the literature of the taxon (Gibbs et al., 2010; Marinoni et al., 2001; Nahas et al., 2012).

In order to quantify leaf area lost by herbivory, we randomly collect 25 leaves of each plant. The leaves were scanned and the damage area quantified using the ImageJ software. To assess plant defenses against herbivory, we measured the specific leaf area (SLA; physical defense caused by sclerophilly) and number of active extrafloral nectaries (EFNs; biotic defense in form of ant attractor). For the first variable, the leaves were dried, weighed and measured and the values of SLA per plant were obtained according to the protocol proposed by Cornelissen et al. (2003). For the second variable, all nectaries of each leaf were counted, and also obtained the average per plant.

\subsection{Data analysis}

All variables were transformed by square root function for account data, or logarithm function for measure data. Normality and homoscedasticity tested using Lilliefors and Lavene analysis, respectively. The mean richness and abundance of all arthropods (dependent variables) were compared between areas (independent variable) using t-test for independent samples (plant individuals) We compared the composition of arthropods between the areas with Analysis of Similarity using Bray-Curtis Index (ANOSIM; Clarke, 1993) followed by Non-Metric Multidimensional Scaling (NMDS). The number of NEFs per leaf were compared between areas (independent) using t-test for independent samples. The difference in composition of the ant fauna (dependent: species) among areas (independent), and abundance of species (dependent) were tested by Permutation Multivariate Analysis of Variance (NPMANOVA; Anderson, 2001) and the contribution of each species to the difference obtained by SIMPER. The leaf area, specific leaf area, abundance and richness of herbivores, and the leaf area lost (all dependent) were also compared between areas (independent) using t-test for independent samples. Finally, the mean abundance of spiders and other arthropods (dependent) were compared between areas (independent) with Mann-Whitney test. Parametric tests were run with logarithmic transformed data but original data is show in figures and table in form of mean and confidence interval or median and quartiles according with data distribution.

\section{Results}

We collected 291 arthropods belonging to 24 species. Plants of preserved area had 23 species, 13 were exclusives, while plants from the disturbance area had only 10 species, with two exclusives (Table 1). The richness and abundance of all arthropods associated with $S$. glabra was lower for disturbed area (richness: $\mathrm{t}=4.73, \mathrm{df}=38, \mathrm{p}<0.01$; $\mathrm{t}$-test: abundance: $\mathrm{t}=2.79$, $\mathrm{df}=38, \mathrm{p}<0.01$, see Table 2 ). The species composition was different between the areas (ANOSIM: $\mathrm{R}=0.24, \mathrm{p}<0.01$ ), presenting $77.26 \%$ of dissimilarity (NMDS: Stress $=0.23$; axis1: $\mathrm{R}^{2}=0.49$; axis $2: \mathrm{R}^{2}=0.24$, see Figure 1 ).

The number of EFNs was the same in both areas $(25.82 \pm 8.12$, t test: $p>0.05$, Figure $2 a)$. Additionally, the abundance and richness of ants visiting the plant were also equal (Abundance $=8.6 \pm 4.27$; Richness $=2.2 \pm 0.56$; t-test: p>0.05; Table 1). Camponotus (Myrmobrachys) crassus (Mayr 1862), Camponotus fastigatus (Roger 1863) and Brachymyrmex heeri (Forel 1874) were the only species present in both sampled location. However, the relative abundance of each species was different (NPMANOVA: $\mathrm{F}=4.83, \mathrm{p}<0.01)$. The plants from the preserved area were dominated by $C$. crassus, while $B$. heeri was more abundant in the disturbed area (Figure 2b).

Plants from both areas had the same leaf area and specific leaf area (t-test: $p>0.05$; Figure $3 a, b)$. However, the abundance and richness of herbivores were higher for the preserved area ( $\mathrm{t}$-test: $\mathrm{t}=2.09, \mathrm{df}=38, \mathrm{p}<0.5$, Figure $3 \mathrm{c}, \mathrm{d})$. There were higher herbivory per plants in the disturbed area ( $\mathrm{t}$ test: $\mathrm{t}=2.76, \mathrm{df}=38, \mathrm{p}<0.01 ; \mathrm{t}=4.37$, $\mathrm{df}=38, \mathrm{p}<0.001$, respectively; Figure $3 \mathrm{e}$ ).

The preserved area had higher number of species and individuals of spiders than the disturbed area (MannWhitney: $p<0.001$; richness: $U=37, N=40$, abundance: $\mathrm{U}=41, \mathrm{~N}=40, \mathrm{p}<0.001$; Table 2). Other arthropods such as mites and cockroaches did not vary significantly between the areas (Mann-Whitney: $\mathrm{p}>0.05$, Table 2).

\section{Discussion}

As far we know, this is the only study that evaluates the effects of human disturbance ant-plant interactions on Cangas in Brazil. Our study shows that human disturbance, such as urbanization, fire and exotic species, can not only simplify the fauna associated with a plant as mutualistic interactions also harm through loss of key species of the interaction. All the diversity associated with S. glabra proved being vulnerable to human disturbance. Studies of the effects of human disturbance on interactions are scarce but some can be found to community structure.

Urbanization itself can lead to critical changes of arthropod community and affect neighboring native areas, either through the invasion of exotic species or reduction of species richness (McIntyre, 2000). The loss or alteration of the abundance and distribution of species alters 
Table 1. List of species and its abundances in both disturbed and preserved areas.

\begin{tabular}{|c|c|c|c|}
\hline & \multicolumn{2}{|c|}{ Abundance } & \multirow{3}{*}{ Group } \\
\hline & \multicolumn{2}{|c|}{ Area } & \\
\hline & Preserved & Disturbed & \\
\hline \multicolumn{4}{|l|}{ Phylum Arthropoda } \\
\hline \multicolumn{4}{|l|}{ Class Insecta } \\
\hline Order Blattodea & 3 & 0 & Other \\
\hline \multicolumn{4}{|l|}{ Order Coleoptera } \\
\hline Family Bostrichidae & 0 & 3 & Herbivore \\
\hline Family Coccinellidae & 1 & 1 & Predator \\
\hline Family Tenebrionoidea & 1 & 0 & Other \\
\hline Order Collembola & 13 & 3 & Other \\
\hline \multicolumn{4}{|l|}{ Order Hemiptera } \\
\hline Family Cycadidae & 0 & 1 & Herbivore \\
\hline Family Myridae & 3 & 0 & Herbivore \\
\hline Family Pentatomidae & 2 & 0 & Herbivore \\
\hline Family Thyreocoridae & 13 & 1 & Herbivore \\
\hline \multicolumn{4}{|l|}{ Order Hymenoptera } \\
\hline \multicolumn{4}{|l|}{ Family Formicidae } \\
\hline Brachymyrmex heeri & 2 & 37 & Ants \\
\hline Camponotus crassus & 94 & 36 & Ants \\
\hline Camponotus fastigatus & 3 & 0 & Ants \\
\hline Family Chalcididae & 12 & 3 & Other \\
\hline Order Lepidoptera & 5 & 0 & Herbivore \\
\hline \multicolumn{4}{|l|}{ Order Orthoptera } \\
\hline Family Tettigoniidae & 1 & 0 & Herbivore \\
\hline Order Thysanoptera & 5 & 2 & Herbivore \\
\hline \multicolumn{4}{|l|}{ Class Arachnida } \\
\hline \multicolumn{4}{|l|}{ Order Araneae } \\
\hline Family Anyphaenidae & 18 & 0 & Spider \\
\hline \multicolumn{4}{|l|}{ Family Araneidae } \\
\hline Araneus corporosus & 1 & 0 & Spider \\
\hline Araneus sp.2 & 1 & 0 & Spider \\
\hline Mago sp.1 & 1 & 0 & Spider \\
\hline Sanogasta sp.1 & 10 & 0 & Spider \\
\hline Youngest & 7 & 0 & Spider \\
\hline Family Salticidae & 3 & 2 & Spider \\
\hline Order Ixodida & 3 & 2 & Other \\
\hline
\end{tabular}

Table 2. Comparative data of abundance and richness for arthropod groups in both disturbed and preserved areas.

\begin{tabular}{lcccccc}
\hline \multirow{2}{*}{ Group } & \multicolumn{2}{c}{ Total (abundance; richness) } & \multicolumn{2}{c}{ Abundance per plant $(\mathbf{n}=20)$} & \multicolumn{2}{c}{ Richness per plant (n=20) } \\
\cline { 2 - 7 } & Preserved & Disturbed & Preserved & Disturbed & Preserved & Disturbed \\
\hline Ants $^{1}$ & $99 ; 3$ & $73 ; 2$ & $4.95 \pm 2.56$ & $3.65 \pm 3.5$ & $1.05 \pm 0.6$ & $1.15 \pm 0.58$ \\
Herbivores $^{1}$ & $29 ; 6$ & $7 ; 4$ & $1.35 \pm 1.08^{*}$ & $0,7 \pm 0,2^{*}$ & $1.05 \pm 0.75^{*}$ & $0,45 \pm 0,1^{*}$ \\
Spiders $^{2}$ & $41 ; 7$ & $2 ; 1$ & $1.0(0 ; 3.5)^{* *}$ & $0(0 ; 0)^{* *}$ & $1.0(1 ; 2)^{* *}$ & $0(0 ; 0)^{* *}$ \\
Others $^{2}$ & $32 ; 5$ & $8 ; 2$ & $1.0(0 ; 1.5)^{* *}$ & $0(0 ; 0.5)^{* *}$ & $1.0(0 ; 1.5)^{* *}$ & $0(0 ; 0,5)^{* *}$ \\
Total $^{1}$ & $201 ; 23$ & $90 ; 10$ & $3.06 \pm 1.02^{*}$ & $2.2 \pm 0.82^{*}$ & $2.42 \pm 0.67^{*}$ & $1.57 \pm 0.43^{*}$ \\
\hline
\end{tabular}

${ }^{1}$ abundance and richness per plant presented as mean \pm standard deviation; ${ }^{2}$ abundance and richness per plant presented as median (lower; upper quartile); ${ }^{*}$ t-test: $\mathrm{p}<0.05$; $^{* *} \mathrm{U}$-test: $\mathrm{p}<0.05$.

ecosystem processes, ecological interactions, ecosystem resilience to changes and consequently the environmental services (Chapin et al., 2000). The entry of invasive species is an important consequence of human alteration of the environment and leads to reduced local diversity (King and Tschinkel, 2008). However, the conservation of interactions, such as mutualisms by seed-dispersers or pollinators, can reduce or even prevent the entry of alien species (Christian, 2001; Kearns et al., 1998).

Environmental disturbances directly reduce plant diversity in a community through changes in environmental conditions such as physical and chemical changes of soil, 


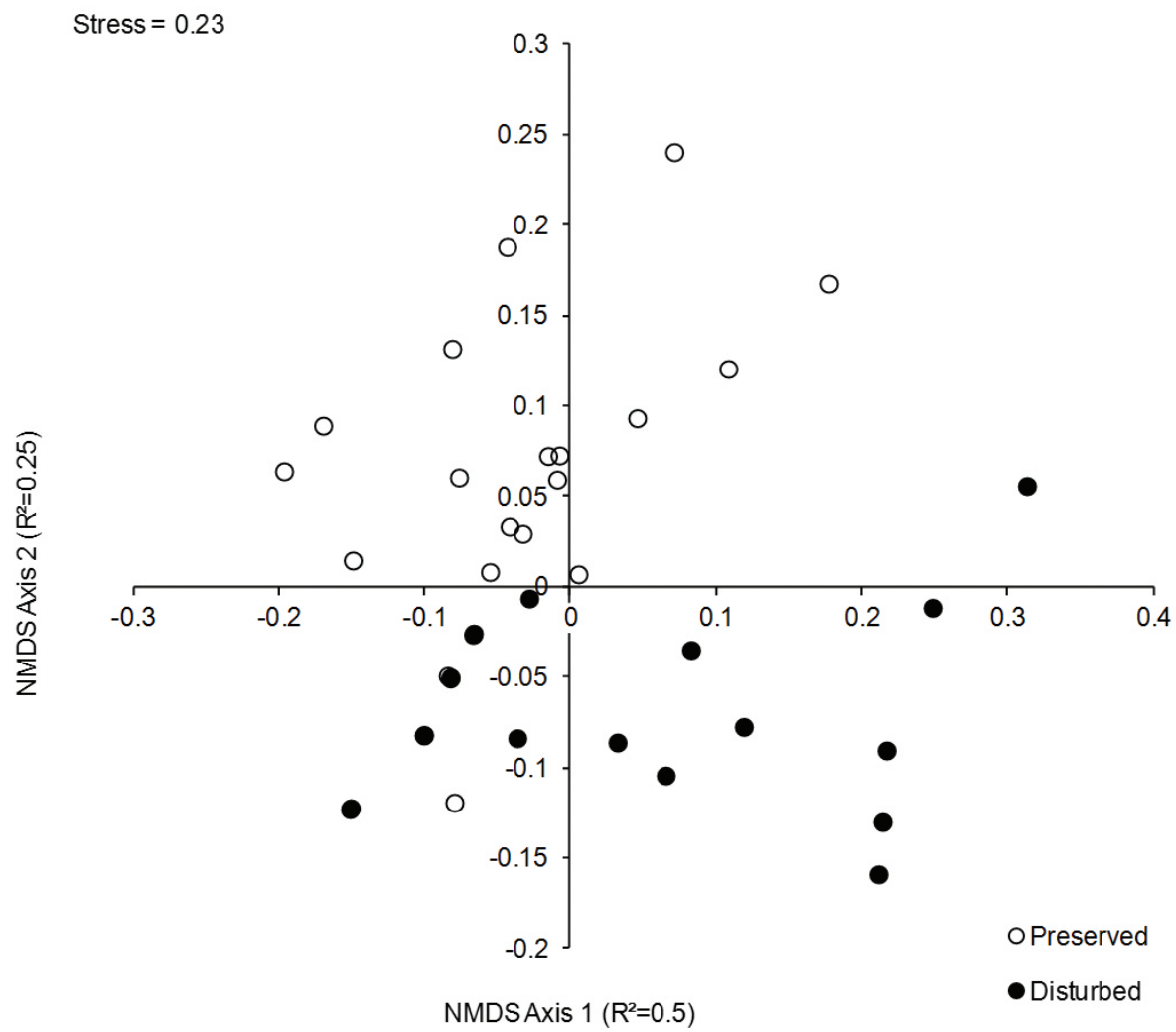

Figure 1. NMDS plot showing the difference between areas on the composition of the arthropod fauna based on the abundance distribution of species using the Bray-Curtis index as a measure of similarity (ANOSIM: $\mathrm{R}=0.24, \mathrm{p}<0.01$; NMDS: Stress $=0.23$; axis $1: \mathrm{R}^{2}=0.49$, axis $2: \mathrm{R}^{2}=0.24$ ).
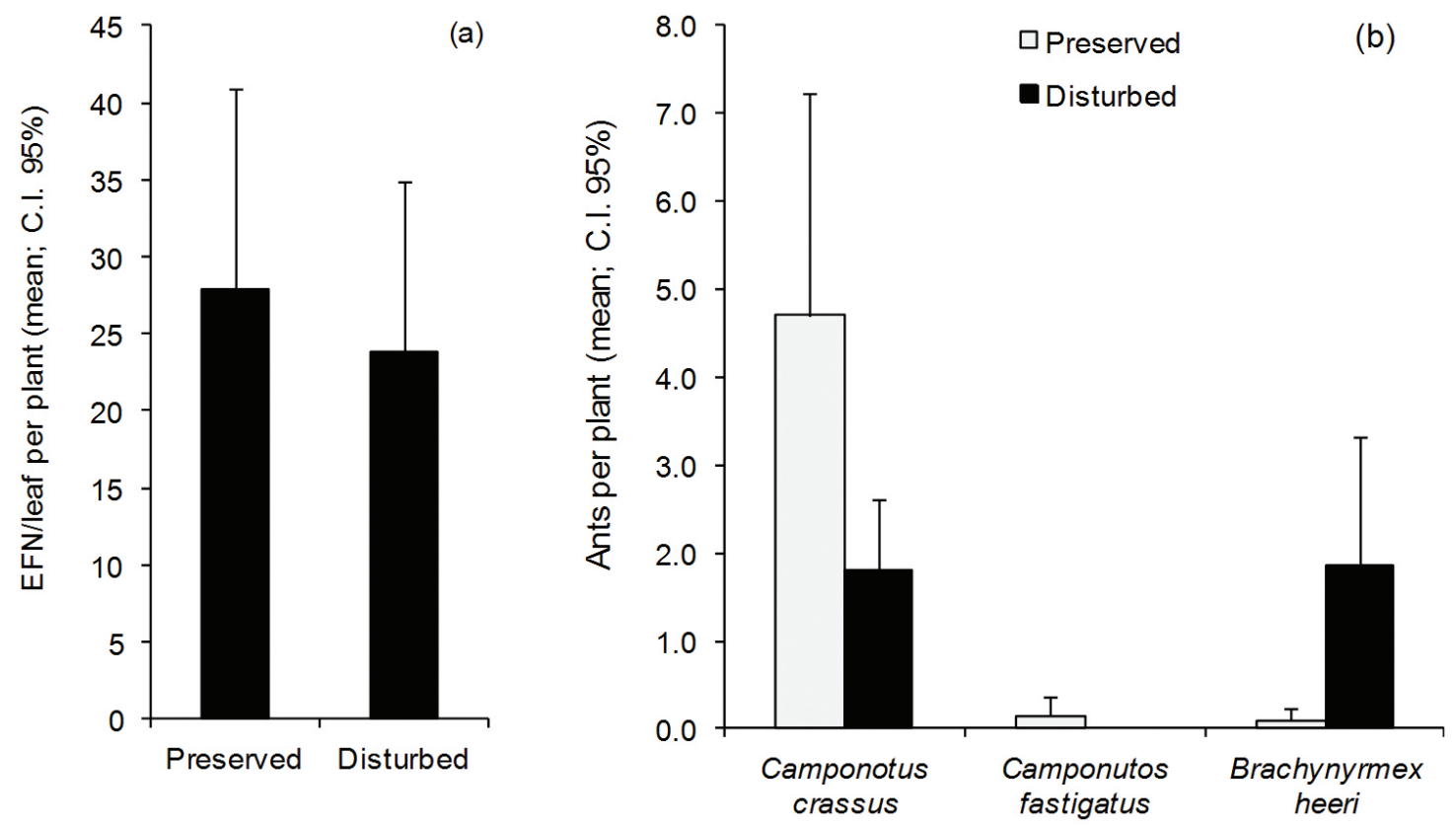

Figure 2. The plants showed the same number of extrafloral nectaries per leaf independent of disturbance (left graph(a)). However, the number of foraging ants was higher in the preserved area (right graph (b); Abundance $=8.6 \pm 4.27$; Richness $=2.2 \pm 0.56$; t-test, $\mathrm{p}>0.05$ ). Additionally, only the preserved area had a numerically dominant ant specie, Camponotus crassus (NPMANOVA: $\mathrm{F}=4.83, \mathrm{p}<0.01$ ). The bars indicate standard deviation. 

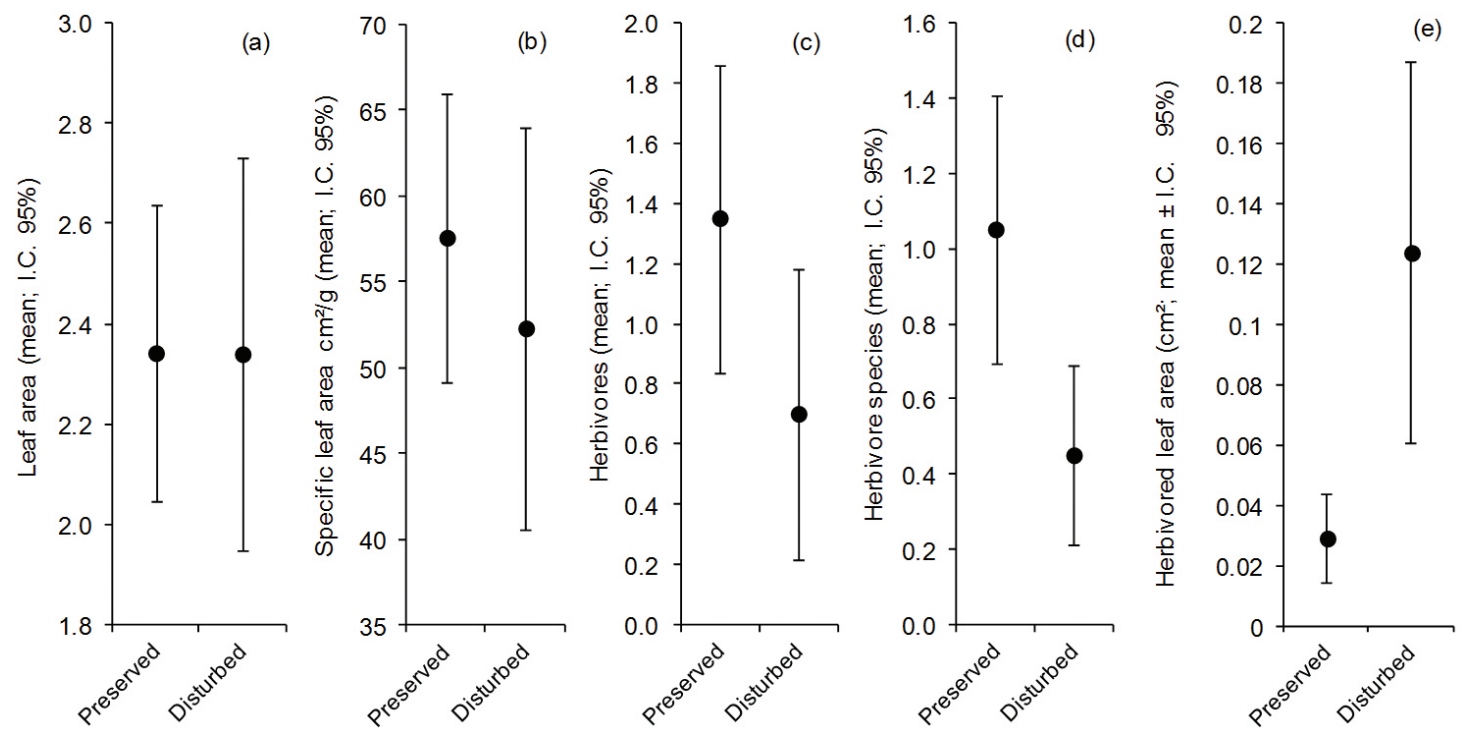

Figure 3. The plants have the same leaf area (a) and specific leaf area (b), but the preserved area was higher abundance and richness of herbivores (c and d). It was the disturbed area that suffered the greatest damage by herbivory (leaf area lost, e: $\mathrm{t}$ test: $\mathrm{t}=3.23, \mathrm{df}=38, \mathrm{p}<0: 01)$. The bars indicate standard deviation.

destruction of habitats and species removal (McIntyre and Lavorel, 1994). Indirectly, this leads to reduced arthropod diversity through loss of resources and microhabitats (Bolger et al., 2000). For ants is even more serious because their diversity is directly related to heterogeneity and plant richness and diversity of habitats and resources (Endringer et al., 2007; Ribas et al., 2003; Schmidt et al., 2007), since most of the ants eating foods derived from plants (Blüthgen et al., 2003). This loss of species leads to breakage of ecological interactions and compromising of community through disruption of trophic webs, facilitating entry of diseases and exotic species, weakening interactions involving plants and animals (mutualisms and herbivory) and extinguishing top predators (Tylianakis et al., 2008). The loss of keystones species, whose interactions are very important to the community, it is even more detrimental to the maintenance of functionality of the community (Mills et al., 1993).

Anthropogenic disturbances cause a reduction in diversity of arthropods associated with vegetation and changes the composition of species (Floren and Linsenmair, 2001). These authors found a reduction in the number of ants along with an increase in the number of herbivores (Lepidoptera larvae) after removal of vegetation. Lopes and Vasconcelos (2011) have shown that disruption of fire increase the amount of herbivores and damage caused by them in the forest. Basset et al. (2008), showed that disturbed forest areas with gardens, planting or removal of vegetation, have low arthropod diversity in vegetation, but high abundance of herbivores. In the Cerrado, habitat of S. glabra, fire is a major disturbance, leading to reduced abundance and richness of arthropods (Vasconcelos et al., 2009).
Stachytarpheta glabra produces the same amount of EFNs regardless of the presence of disturbances. Thus, plants of both the areas were visited by the same amount of ants. In the Cerrado, Banisteopsis campestris showed higher nectar production in post-fire regrowth, leading to greater amount of ants visiting and lower herbivory (Alves-Silva and Del-Claro, 2013). But the S. glabra from the disturbed area showed higher amount of herbivory, even with a lower abundance of herbivores. So, something beyond the amount of visiting ants determined the high degree of herbivory suffered by S. glabra.

Our study shows that $S$. glabra in disturbed areas present an inefficient protector and a consequent higher herbivory level. In the disturbed area, we found reduced abundance and richness of herbivore predators along with a relatively lower abundance of aggressive ants visiting S. glabra, resulting in higher herbivory damage than in a preserved area, and despite a similar investment in defense against herbivores (density of EFNs and leaf sclerophylly). Lopes and Vasconcelos (2011) found a greater amount of herbivory in disturbed areas, but detained their discussion to the supposed low amount of defenses in leaf regrowth of plants in disturbed areas poor in nutrients and oblivious to the possible low amount of predators.

Each ant species provides a particular degree of protection of plants, and many species together are little or no effective in protection of plants (Oliveira and DelClaro, 2005; Rosumek et al., 2009). Ant species which are small, fragile and non-aggressive usually play the role of nectar robbers providing no benefit to the plant or another mutualistic partner (Byk and Del-Claro, 2010, 2011; Oliveira and Del-Claro, 2005). Thus, despite the similar number of ants collecting nectar, the identities of 
the species and its relative abundances may explain the observed differences between the areas to leaf damages.

The amount and identity of ant species visiting a plant myrmecophytic interaction is determined by the amount and quality of extrafloral nectar (Lange et al., 2013; Rico-Gray and Oliveira, 2007). However, investment of the plant in attracting ants can be influenced by the plant species, the phenology and ontogeny of the plant and EFNs and by external factors such as changes in climate and habitat (Lange et al., 2013; Oliveira and Freitas, 2004; Queiroz et al., 2013). In our study, S. glabra showed no induction or increased biotic defense (EFNs) and physical (sclerophylly) in response to environmental disturbance but still showed higher herbivory in the disturbed area. Thus, the more damage can be the result of inefficient defense provided by the ant species $B$. heeri, showing a high dependence of protective ants over the non-regulation of constitutive defenses. As the ant fauna available for interaction is a result of the environment quality, the human perturbations indirectly affect the results of the interaction S.glabra-ants-herbivores through the unavailability of species capable of defending the plant.

Studies with ant-plant interactions through ENFs in Cerrado show that $C$. crassus is the most common and abundant specie in ant-plant interactions involving extrafloral nectaries and exsudate-producer herbivores (Lange et al., 2013; Rico-Gray and Oliveira, 2007; Schoereder et al., 2010). Although $B$. heeri was present but presents no aggressiveness (Rico-Gray and Oliveira, 2007). Camponotus crassus is considered a dominant arboreal ant and natural sugary secretion consumer (DelClaro and Oliveira, 1999, 2000; Fagundes et al., 2012; Goitía and Jaffé, 2009; Rico-Gray and Oliveira, 2007). This means that its large size, aggressiveness, presence of attack mechanisms (namely acidoporo ejector of formic acid), and territorial behavior are key characters that make this species suitable for defense of plants and removing and driving away herbivores and thus reducing herbivory, ensuring the benefits of mutualism (Fagundes et al., 2012; Freitas and Oliveira, 1992).

The high rate of herbivory on S. glabra in disturbed area cannot be explained by the abundance of herbivores, which in turn may be a response to disturbances (Ayres and Lombardero, 2000; Huntly, 1991). Even in low numbers, the presence of one or a few species of herbivores can lead to higher leaf damage (Coley and Barone, 1996), since even low abundance in a herbivore is able to spend more time in the plant and feeding access a large number of plants when it finds its natural enemy, increasing your damage (Beckerman et al., 1997; Byrnes et al., 2006). However, no species of herbivore collected presented a much higher abundance in the disturbed area. Thus, the lack of aggressive ant species also helps to explain the high rate of herbivory. Furthermore, the low abundance of predators and parasitoids of plant-disturbed area may promote the activity of herbivorous (Beckerman et al., 1997; Nahas et al., 2012). Spiders are important predators associated vegetation, and its absence may lead to high rates of herbivory on the plant, especially when associated with low abundance of ants (Nahas et al., 2012).

Stachytarpheta glabra has its trade-off in defense moved to biotic defenses indicated by the particular high production of EFNs. As the human disturbance cause a simplification of the ant fauna (Costa et al., 2010), the diversity of herbivore enemies is reduced, facilitating access and consequently high herbivory damages (McEvoy et al., 1993). S. glabra may be considered as a key-specie for the dynamics and maintenance of ferruginous rupestrian fields (Jacobi and Antonini, 2008; Jacobi et al., 2008). As successional early species, $S$. glabra modifies the environment making it more suitable for forward species in succession process (Bustamante-Sànchez et al., 2011; Connell and Slatyer, 1977; Padilla and Pugnaire, 2006; Whittaker, 1975). However, its establishment and proper development in the post-disturbance environment depends severely on the arthropod fauna associated (Brown, 1985; Brown and Gange, 1992; De Deyn et al., 2003). The present data adds a new level of concern, the interactions diversity, about the conservation and urgent need of protection and management of this ecosystem which is one of the most threaten.

\section{Acknowledgements}

We would like to thank Mr. Ivan Luiz Fiorini de Magalhães (Department of General Biology, Federal University of Minas Gerais) for the identification of Arachnida. The authors are grateful to the reviewers for their comments and suggestions that helped to improve this work.

\section{References}

AGRAWAL, AA. and RUTTER, MT., 1998. Dynamic anti-herbivore defense in ant-plants: the role of induced responses. Oikos, vol. 83 , no. 2, p. 227-236. http://dx.doi.org/10.2307/3546834.

ALMEIDA, AM. and FIGUEIREDO, RA., 2003. Ants visit nectaries of Epidendrum denticulatum (Orchidaceae) in a Brazilian rainforest: effects on herbivory and pollination. Brazilian journal of biology $=$ Revista brasleira de biologia, vol. 63, no. 4, p. 551-558. http:// dx.doi.org/10.1590/S1519-69842003000400002. PMid:15029366

ALVES-SILVA, E., 2011. Post fire resprouting of Banisteriopsis malifolia (Malpighiaceae) and the role of extrafloral nectaries on the associated ant fauna in a Brazilian Savanna. Sociobiology, vol. 58 , no. 2 , p. $327-340$

ALVES-SILVA, E. and DEL-CLARO, K., 2013. Effect of postfire resprouting on leaf fluctuating asymmetry, extrafloral nectar quality, and ant-plant-herbivore interactions. Naturwissenschaften, vol. 100, no. 6, p. 525-532. http://dx.doi.org/10.1007/s00114-0131048-z. PMid:23625518

ANDERSON, MJ., 2001. A new method for non-parametric multivariate analysis of variance. Austral Ecology, vol. 26, no. 1, p. 32-46

ANTONINI, Y., SOUZA, HG., JACOBI, CM. and MURY, FB., 2005. Diversidade e comportamento dos insetos visitantes florais de Stachytarpheta glabra (Verbenaceae) em uma área de campo ferruginoso, Ouro Preto, MG. Neotropical Entomology, 
vol. 34, no. 4, p. 555-564. http://dx.doi.org/10.1590/S1519566X2005000400004.

AYRES, MP. and LOMBARDERO, MJ., 2000. Assessing the consequences of global change for forest disturbance from herbivores and pathogens. The Science of the Total Environment, vol. 262, no. 3, p. 263-286. http://dx.doi.org/10.1016/S00489697(00)00528-3. PMid:11087032

BASSET, Y., MISSA, O., ALONSO, A., MILLER, SE., CURLETTI, G., DE MEYER, M., EARDLEY, C., LEWIS, OT., MANSELL, MW., NOVOTNY, V. and WAGNER, T., 2008. Changes in arthropod assemblages along a wide gradient of disturbance in Gabon. Conservation biology: the journal of the Society for Conservation Biology, vol. 22, no. 6, p. 1552-1563. http://dx.doi. org/10.1111/j.1523-1739.2008.01017.x. PMid:18717696

BECKERMAN, AP., URIARTE, M. and SCHMITZ, OJ., 1997. Experimental evidence for a behavior-mediated trophic cascade in a terrestrial food chain. Proceedings of the National Academy of Sciences of the United States of America, vol. 94, no. 20, p. 10735-10738. http://dx.doi.org/10.1073/pnas.94.20.10735. PMid:11038581

BEGON, M., MORTIMER, M. and THOMPSON, D., 1996. Population Ecology: a unified study of animals and plants. 3rd ed. Oxford: Blackwell Science. 220 p. http://dx.doi. org/10.1002/9781444313765.

BENTLEY, BL., 1977. Extrafloral nectaries and protection by pugnacious bodyguards. Annual Review of Ecology and Systematics, vol. 8, no. 1, p. 407-427. http://dx.doi.org/10.1146/ annurev.es.08.110177.002203.

BLÜTHGEN, N., GEBAUER, G. and FIEDLER, K., 2003. Disentangling a rainforest food web using stable isotopes: dietary diversity in a species-rich ant community. Oecologia, vol. 137, no. 3, p. 426-435. http://dx.doi.org/10.1007/s00442-003-1347-8. PMid:12898386

BOLGER, DT., SUAREZ, AV., CROOKS, KR., MORRISON, SA. and CASE, TJ., 2000. Arthropods in urban habitat fragments in southern California: area, age and edge effects. Ecological Applications, vol. 10, no. 4, p. 1230-1248. http://dx.doi. org/10.1890/1051-0761(2000)010[1230:AIUHFI]2.0.CO;2.

BROWN, JH., 1985. Organization of North American desert rodent associations: insights from geographic comparisons and perturbation experiments. Australian Mammalogy, vol. 8, no. 3, p. 131-136.

BROWN, VK. and GANGE, AC., 1992. Secondary plant succession: how is it modified by insect herbivory? Vegetatio, vol. 101, no. 1, p. 3-13. http://dx.doi.org/10.1007/BF00031910.

BUSTAMANTE-SÁNCHEZ, MA., ARMESTO, JJ. and HALPERN, CB., 2011. Biotic and abiotic controls on tree colonization in three early successional communities of Chiloé Island, Chile. Journal of Ecology, vol. 99, no. 1, p. 288-299. http://dx.doi. $\operatorname{org} / 10.1111 / \mathrm{j} .1365-2745.2010 .01737 . x$.

BYK, J. and DEL-CLARO, K., 2010. Nectar and pollen-gathering Cephalotes ants provide no protection against herbivory: a new manipulative experiment to test ant protective capabilities. Acta Ethologica, vol. 13, no. 1, p. 33-38. http://dx.doi.org/10.1007/ s10211-010-0071-8.

BYK, J. and DEL-CLARO, K., 2011. Ant-plant interaction in the Neotropical savanna: direct beneficial effects of extrafloral nectar on ant colony fitness. Population Ecology, vol. 53, no. 2, p. 327-332. http://dx.doi.org/10.1007/s10144-010-0240-7.
BYRNES, J., STACHOWICZ, JJ., HULTGREN, KM., RANDALL HUGHES, A., OLYARNIK, SV. and THORNBER, CS., 2006. Predator diversity strengthens trophic cascades in kelp forests by modifying herbivore behaviour. Ecology Letters, vol. 9, no. 1, p. 61-71. PMid:16958869.

CHAPIN, FS 3rd., ZAVALETA, ES., EVINER, VT., NAYLOR, RL., VITOUSEK, PM., REYNOLDS, HL., HOOPER, DU., LAVOREL, S., SALA, OE., HOBBIE, SE., MACK, MC. and DÍAZ, S., 2000. Consequences of changing biodiversity. Nature, vol. 405, no. 6783, p. 234-242. http://dx.doi.org/10.1038/35012241. PMid:10821284

CHRISTIAN, CE., 2001. Consequences of a biological invasion reveal the importance of mutualism for plant communities. Nature, vol. 413, no. 6856, p. 635-639. http://dx.doi.org/10.1038/35098093. PMid:11675787

CLARKE, KR., 1993. Non-parametric multivariate analyses of changes in community structure. Australian Journal of Ecology, vol. 18, no. 1, p. 117-143. http://dx.doi.org/10.1111/j.1442-9993.1993. tb00438.x.

COLEY, PD. and BARONE, JA., 1996. Herbviory and plant defenses in tropical forests. Annual Review of Ecology and Systematics, vol. 27, no. 1, p. 305-335. http://dx.doi.org/10.1146/ annurev.ecolsys.27.1.305.

CONNELL, JH. and SLATYER, RO., 1977. Mechanisms of succession in natural communities and their role in community stability and organization. American Naturalist, vol. 111, no. 982, p. 1119-1144. http://dx.doi.org/10.1086/283241.

CORNELISSEN, JHC., LAVOREL, S., GARNIER, E., DÍAZ, S., BUCHMANN, N., GURVICH, DE., REICH, PB., STEEGE, H., MORGAN, HD., VAN DER HEIJDEN, MGA., PAUSAS, JG. and POORTER, H., 2003. A handbook of protocols for standardized and easy measurement of plant functional traits worldwide. Australian Journal of Botany, vol. 51, no. 4, p. 335-380. http:// dx.doi.org/10.1071/BT02124.

COSTA, CB., RIBEIRO, SP. and CASTRO, PTA., 2010. Ants as bioindicators of natural succession in savanna and riparian vegetation impacted by dredging in the Jequitinhonha River Basin. Brazilian Restoration Ecology, vol. 18, no. 1, p. 148-157. http:// dx.doi.org/10.1111/j.1526-100X.2009.00643.x.

DE DEYN, GB., RAAIJMAKERS, CE., ZOOMER, HR., BERG, MP., DE RUITER, PC., VERHOEF, HA., BEZEMER, TM. and VAN DER PUTTEN, WH., 2003. Soil invertebrate fauna enhances grassland succession and diversity. Nature, vol. 422, no. 6933, p. 711-713. http://dx.doi.org/10.1038/nature01548. PMid:12700759

DEL-CLARO, K. and OLIVEIRA, PS., 1999. Ant-homoptera interactions in a neotropical savanna: the honeydew-producing treehopper Guayaquila xiphias (Membracidae) and its associated ant fauna on Didymopanax vinosum (Araliaceae). Biotropica, vol. 31 , no. 1, p. 135-144.

DEL-CLARO, K. and OLIVEIRA, PS., 2000. Conditional outcomes in a neotropical treehopper-ant association: temporal and species-specific variation in ant protection and homopteran fecundity. Oecologia, vol. 124, no. 2, p. 156-165. http://dx.doi. org/10.1007/s004420050002.

DEL-CLARO, K. and TOREZAN-SILINGARDI, HM., 2009. Insect-plant interactions: new pathways to a better comprehension of ecological communities in Neotropical savannas. Neotropical Entomology, vol. 38, no. 2, p. 159-164. http://dx.doi.org/10.1590/ S1519-566X2009000200001. PMid:19488503 
DEL-CLARO, K., BERTO, V. and RÉU, W., 1996. Effect of herbivore deterrence by ants on the fruit set of an extrafloral nectary plant, Qualea multiflora (Vochysiaceae). Journal of Tropical Ecology, vol. 12, no. 6, p. 887-892. http://dx.doi.org/10.1017/ S0266467400010142.

DRUMMOND, AJ., RAMBAUT, A., SHAPIRO, B. and PYBUS, OG., 2005. Bayesian coalescent inference of past population dynamics from molecular sequences. Molecular Biology and Evolution, vol. 22, no. 5, p. 1185-1192. http://dx.doi.org/10.1093/ molbev/msi103. PMid: 15703244

ENDRINGER, FB., RIBAS, CR., SANTOS, IA. and SCHOEREDER, JH., 2007. Uso de formigas como indicadoras de recuperação após impacto ambiental por queimada. O Biológico, vol. 69, no. 2 , p. 313-315.

FAGUNDES, R., DEL-CLARO, K. and RIBEIRO, SP., 2012. Effects of the trophobiont herbivore Calloconophora pugionata (Hemiptera) on ant fauna associated with Myrcia obovata (Myrtaceae) in a montane tropical forest. Psyche, vol. 2012, p. 1-8. http://dx.doi.org/10.1155/2012/783945.

FAGUNDES, R., RIBEIRO, SP. and DEL-CLARO, K., 2013. Tending-ants increase survivorship and reproductive success of Calloconophora pugionata Drietch (Hemiptera, Membracidae), a trophobiont herbivore of Myrcia obovata O.Berg (Myrtales, Myrtaceae). Sociobiology, vol. 60, no. 1, p. 11-19. http://dx.doi. org/10.13102/sociobiology.v60i1.11-19.

FLOREN, A. and LINSENMAIR, KE., 2001. The influence of anthropogenic disturbances on the structure of arboreal arthropod communities. Plant Ecology, vol. 153, no. 1-2, p. 153-167. http:// dx.doi.org/10.1023/A:1017510312462.

FREITAS, AVL. and OLIVEIRA, PS., 1992. Biology and behavior of the neotropical butterfly Eunica bechina (Nymphalidae), with special reference to larval defense against ant predation. Journal of Research on the Lepidoptera, vol. 31, no. 1-2, p. 1-11.

GIBBS, HK., RUESCH, AS., ACHARD, F., CLAYTON, MK., HOLMGREN, P., RAMANKUTTY, N. and FOLEY, JA., 2010. Tropical forests were the primary sources of new agricultural land in the 1980s and 1990s. Proceedings of the National Academy of Sciences of the United States of America, vol. 107, no. 38, p. 16732-16737. http://dx.doi.org/10.1073/pnas.0910275107. PMid:20807750

GIULIETTI, AM., HARLEY, RM., QUEIROZ, LP., WANDERLEY, MG. and VAN DEN BERG, C., 2005. Biodiversidade e conservação das plantas no Brasil. Megadiversidade, vol. 1, no. 1, p. 52-61.

GOITÍA, W. and JAFFÉ, K., 2009. Ant-plant associations in different forests in Venezuela. Neotropical Entomology, vol. 38, no. 1, p. 753-777. http://dx.doi.org/10.1590/S1519-566X2009000100002. PMid:19347094

HEIL, M., HILPERT, A., KRÜGER, R. and LINSENMAIR, KE., 2004. Competition among visitors to extrafloral nectaries as a source of ecological costs of an indirect defense. Journal of Tropical Ecology, vol. 20, no. 2, p. 201-208. http://dx.doi. org/10.1017/S026646740300110X.

HEIL, M., KOCH, T., HILPERT, A., FIALA, B., BOLAND, W. and LINSENMAIR, K., 2001. Extrafloral nectar production of the ant-associated plant, Macaranga tanarius, is an induced, indirect, defensive response elicited by jasmonic acid. Proceedings of the National Academy of Sciences of the United States of America, vol. 98, no. 3, p. 1083-1088. http://dx.doi.org/10.1073/pnas.98.3.1083. PMid:11158598
HUNTLY, N., 1991. Herbivores and the dynamics of communities and ecosystems. Annual Review of Ecology and Systematics, vol. 22, no. 1, p. 477-503. http://dx.doi.org/10.1146/annurev. es.22.110191.002401

JACOBI, CM. and ANTONINI, Y., 2008. Pollinators and defense of Stachytarpheta glabra (Verbenaceae) nectar resources by the hummingbird Colibri serrirostris (Trochilidae) on ironstone outcrops in south-east Brazil. Journal of Tropical Ecology, vol. 24, no. 3, p. 301-308. http://dx.doi.org/10.1017/S0266467408005051.

JACOBI, CM. and CARMO, FF., 2008. Diversidade dos campos rupestres ferruginosos no Quadrilátero Ferrífero, MG. Megadiversidade, vol. 4, no. 1-2, p. 25-33.

JACOBI, CM., CARMO, FF. and VINCENT, RC., 2008. Estudo fitossociológico de uma comunidade vegetal sobre canga como subsídio para a reabilitação de áreas mineradas no quadrilátero ferrífero, MG. Revista Árvore, vol. 32, no. 2, p. 345-353. http:// dx.doi.org/10.1590/S0100-67622008000200017.

KEARNS, CA., INOUYE, DW. and WASER, NM., 1998. The conservation of plant-pollinator interactions. Annual Review of Ecology and Systematics, vol. 29, no. 1, p. 83-112. http://dx.doi. org/10.1146/annurev.ecolsys.29.1.83.

KING, JR. and TSCHINKEL, WR., 2008. Experimental evidence that human impacts drive fire ant invasions and ecological change. Proceedings of the National Academy of Sciences of the United States of America, vol. 105, no. 51, p. 20339-20343. http://dx.doi. org/10.1073/pnas.0809423105. PMid:19064909

LACH, L., PARR, CL. and ABBOTT, KL., 2010. Ant Ecology. New York: Oxford University Press. 424 p.

LANGE, D., DÁTTILO, W. and DEL-CLARO, K., 2013. Influence of extrafloral nectary phenology on ant-plant mutualistic networks in a neotropical savana. Ecological Entomology, vol. 38, no. 5, p. 463-469. http://dx.doi.org/10.1111/een.12036.

LOPES, CT. and VASCONCELOS, HL., 2011. Fire Increases Insect Herbivory in a Neotropical Savanna. Biotropica, vol. 43, no. 5, p. 612-618. http://dx.doi.org/10.1111/j.1744-7429.2011.00757.x.

MARGULIS, L. and FESTER, R., 1991. Symbiosis as a Source of Evolutionary Innovation: speciation and morphogenesis. 1st ed. Cambridge: MIT Press. 470 p.

MARINONI, RC., GANHO, NG., MONNÉ, ML. and MERMUDES, JRM., 2001. Hábitos alimentares em Coleoptera (Insecta). Ribeirão Preto: Holos. 64 p.

MCEVOY, PB., RUDD, NT., COX, CS. and HUSO, M., 1993. Disturbance, competition and herbivory effects on ragwort Senecio jacobaeae populations. Ecological Monographs, vol. 63, no. 1, p. 55-75. http://dx.doi.org/10.2307/2937123.

MCINTYRE, NE., 2000. Ecology of Urban Arthropods: A Review and a Call to Action. Annals of the Entomological Society of America, vol. 93, no. 4, p. 825-835. http://dx.doi.org/10.1603/00138746(2000)093[0825:EOUAAR]2.0.CO;2.

MCINTYRE, S. and LAVOREL, S., 1994. Predicting richness of native, rare, and exotic plants in response to habitat and disturbance variables across a variegated landscape. Conservation Biology, vol. 8, no. 2 , p. 521-531. http://dx.doi.org/10.1046/j.15231739.1994.08020521.x

MILLS, LS., SOULÉ, ME. and DOAK, DF., 1993. The keystonespecies concept in ecology and conservation. Bioscience, vol. 43, no. 4, p. 219-224. http://dx.doi.org/10.2307/1312122. 
MONDOR, EB. and ADDICOTT, JF., 2003. Conspicuous extra-floral nectaries are inducible in Vicia faba. Ecology Letters, vol. 6, no. 6, p. 495-497. http://dx.doi.org/10.1046/j.1461-0248.2003.00457.x.

NAEEM, S., 1998. Species redundancy and ecosystem reliability. Conservation Biology, vol. 12, no. 1, p. 39-45. http://dx.doi. org/10.1046/j.1523-1739.1998.96379.x.

NAHAS, L. and DEL-CLARO, K., 2011. Ant-plant interactions: absolute frequency as a better method to sample visiting ants in the extrafloral nectary-bearing plant, Qualea multiflora (Vochysiaceae). Sociobiology, vol. 57 , no. 2, p. 1-7.

NAHAS, L., GONZAGA, MO. and DEL-CLARO, K., 2012. Emergent impacts of ants and spider interactions: herbivory reduction in a tropical savanna tree. Biotropica, vol. 44, no. 4, p. 498-505. http://dx.doi.org/10.1111/j.1744-7429.2011.00850.x.

NESS, JH., 2003. Catalpa bignonioides alters extrafloral nectar production after herbivory and attracts ant bodyguards. Oecologia, vol. 134, no. 2, p. 210-218. PMid:12647162.

OLIVEIRA, PS. and DEL-CLARO, K., 2005. Multitrophic interactions in a Neotropical savanna: ant-hemiptera systems, associated insect herbivores, and a host plant. In: BURSLEM, DFRP., PINARD, MA. and HARTLEY, SE. (Eds.). Biotic interactions in the tropics. Cambridge: Cambridge University Press. p. 414-438.. http://dx.doi.org/10.1017/CBO9780511541971.018.

OLIVEIRA, PS. and FREITAS, AVL., 2004. Ant-plant-herbivore interactions in the neotropical cerrado savanna. Naturwissenschaften, vol. 91, no. 12, p. 557-570. http://dx.doi.org/10.1007/s00114-0040585-x. PMid:15551026

PADILLA, FM. and PUGNAIRE, FI., 2006. The role of nurse plants in the restoration of degraded environments. Frontiers in Ecology and the Environment, vol. 4, no. 4, p. 196-202. http:// dx.doi.org/10.1890/1540-9295(2006)004[0196:TRONPI]2.0.CO;2.

PHILPOTT, SM., PERFECTO, I., ARMBRECHT, I. and PARR, CL., 2010. Ant diversity and function in disturbed and changing habitats. In: LACH, L., PARR, CL. and ABBOTT, KL. (Eds.). Ant Ecology. New York: Oxford University Press. p. 137-156.

PIMM, SL., 1984. The complexity and stability of ecosystems. Nature, vol. 307, no. 5949, p. 321-326. http://dx.doi.org/10.1038/307321a0.

PIOVIA-SCOTT, J., 2011. The effect of disturbance on an antplant mutualism. Oecologia, vol. 166, no. 2, p. 411-420. http:// dx.doi.org/10.1007/s00442-010-1851-6. PMid:21113623

QUEIROZ, ACM., COSTA, FV., NEVES, FS. and FAGUNDES, M., 2013. Does leaf ontogeny lead to change in defensive strategies against insect herbivores? Arthropod-Plant Interactions, vol. 7, no. 1, p. 99-107. http://dx.doi.org/10.1007/s11829-012-9224-1.

RIBAS, CR., SCHOEREDER, JH., PIC, M. and SOARES, SM., 2003. Tree heterogeneity, resource availability, and larger scale processes regulating arboreal ant species richness. Austral Ecology, vol. 28, no. 3, p. 305-314. http://dx.doi.org/10.1046/j.14429993.2003.01290.x.

RIBEIRO, SP., BORGES, PP., GASPAR, C., MELO, C., SERRANO, ARM., AMARAL, J., AGUIAR, C., ANDRE, G. and QUARTAU, JA., 2005. Canopy insect herbivores in the Azorean Laurisilva forests: key host plant species in a highly generalist insect community. Ecography, vol. 28, no. 3, p. 315-330. http:// dx.doi.org/10.1111/j.0906-7590.2005.04104.x.

RICO-GRAY, V. and OLIVEIRA, PS., 2007. The ecology and evolution of ant-plant interactions. 1st ed. Chicago:
University of Chicago Press. 320 p. http://dx.doi.org/10.7208/ chicago/9780226713540.001.0001.

RICO-GRAY, V., OLIVEIRA, PS., PARRA-TABLA, V., CUAUTLE, M. and DÍAZ-CASTELAZO, C., 2004. Ant-plant interactions: their seasonal variation and effects on plant fitness. In: MARTÍNEZ, ML. and PSUTY, N. (Eds.). Coastal dunes: Ecology and Conservation. Berlin: Springer Verlag. p. 221-239.

ROMERO, GQ., 2002. Protection of Vochysia elliptica (Vochysiaceae) by a nectar-thieving ant. Brazilian journal of biology $=$ Revista brasleira de biologia, vol. 62, no. 2, p. 371-373. http://dx.doi. org/10.1590/S1519-69842002000200021. PMid:12489409

ROSIÈRE, CA. and CHEMALE, JRF., 2000. Brazilian iron formations and their geological setting. Revista Brasileira de Geociencias, vol. 30, no. 2, p. 274-278.

ROSUMEK, FB., SILVEIRA, FAO., NEVES, F., BARBOSA, NP., DINIZ, L., OKI, Y., PEZZINI, F., FERNANDES, GW. and CORNELISSEN, T., 2009. Ants on plants: a meta-analysis of the role of ants as plant biotic defenses. Oecologia, vol. 160, no. 3, p. 537-549. http://dx.doi.org/10.1007/s00442-009-1309-x. PMid:19271242

SCHMIDT, FA., SOLAR, RRC., RIBAS, CR. and SCHOEREDER, JH., 2007. Resposta da riqueza de espécies de formigas a um gradiente de sucessão. O Biológico, vol. 69, no. 2, p. 271-274.

SCHOEREDER, JH., GUERRA SOBRINHO, T., MADUREIRA, MS., RIBAS, CR. and OLIVEIRA, PS., 2010. The arboreal ant community visiting extrafloral nectaries in the Neotropical Cerrado savanna. Terrestrial Arthropod Reviews, vol. 3, no. 1, p. 3-27. http://dx.doi.org/10.1163/187498310X487785.

SIX, DL., POULSEN, M., HANSEN, AK., WINGFIELD, MJ., ROUX, J., EGGLETON, P., SLIPPERS, B. and PAINE, TD., 2011. Anthropogenic effects on interaction outcomes: examples from insect-microbial symbioses in forest and savanna ecosystems. Symbiosis, vol. 53, no. 3, p. 101-121. http://dx.doi.org/10.1007/ s13199-011-0119-1.

SOUSA-SOUTO, L., SCHAEFER, CEGR., SCHOEREDER, JH. and LIMA, ER., 2008. Sequestro de carbono por saúvas e sua possível influência na diminuição do efeito estufa. In: VILELA, EF., SANTOS, IA., SCHOEREDER, JH., SERRÃO, JE., CAMPOS, LAO. and LINO-NETO, J. (Eds.). Insetos sociais: da biologia à aplicação. Viçosa: Editora UFV. p. 312-322.

SPILLER, DA. and AGRAWAL, AA., 2003. Intense disturbance enhances plant susceptibility to herbivory: natural and experimental evidence. Ecology, vol. 84, no. 4, p. 890-897. http://dx.doi. org/10.1890/0012-9658(2003)084[0890:IDEPST]2.0.CO;2.

TYLIANAKIS, JM., DIDHAM, RK., BASCOMPTE, J. and WARDLE, DA., 2008. Global change and species interactions in terrestrial ecosystems. Ecology Letters, vol. 11, no. 12, p. 1351-1363. http://dx.doi.org/10.1111/j.1461-0248.2008.01250.x. PMid:19062363

VASCONCELOS, HL., PACHECO, R., SILVA, RC., VASCONCELOS, PB., LOPES, CT., COSTA, AN. and BRUNA, EM., 2009. Dynamics of the leaf-litter arthropod fauna following fire in a neotropical woodland savanna. PLOS ONE, vol. 4, no. 11, p. e7762. http:// dx.doi.org/10.1371/journal.pone.0007762. PMid:19898619

VIANA, PL. and LOMBARDI, JA., 2007. Florística e caracterização dos campos rupestres sobre canga na Serra da Calçada, Minas Gerais, Brasil. Rodriguésia, vol. 58, no. 1, p. 159-177.

VIANA-SILVA, FEC. and JACOBI, CM., 2012. Myrmecofauna of ironstone outcrops: composition and diversity. Neotropical 
Entomology, vol. 41, no. 4, p. 263-271. http://dx.doi.org/10.1007/ s13744-012-0045-9. PMid:23950060

VINCENT, RC., JACOBI, CM. and ANTONINI, Y., 2002. Diversidade na adversidade. Ciência Hoje, vol. 31, no. 185, p. 64-67.

WÄCKERS, FL., ZUBER, D., WUNDERLIN, R. and KELLER, F., 2001. The effect of herbivory on temporal and spatial dynamics of foliar nectar production in cotton and castor. Annals of Botany, vol. 87, no. 3, p. 365-370. http://dx.doi.org/10.1006/anbo.2000.1342.
WEBBER, BL., MOOG, J., CURTIS, ASO. and WOODROW, IE., 2007. The diversity of ant-plant interactions in the rainforest understory tree, Ryparosa (Achariaceae): food bodies, domatia, prostomata, and hemipteran trophobionts. Botanical Journal of the Linnean Society, vol. 154, no. 3, p. 353-371. http://dx.doi. org/10.1111/j.1095-8339.2007.00651.x.

WHITTAKER, RH., 1975. Communities and Ecosystems. 2nd ed. New York: Macmillan Publishing Company. 352 p. 